\title{
Effects of Aqueous and Methanolic Leaf Extracts of Vitex doniana on Lipid Profile and Liver Enzymes of Alloxan Induced Diabetic Albino Rats
}

\author{
${ }^{1}$ Nwogo Ajuka Obasi, ${ }^{2}$ Kalu Mong Kalu, ${ }^{3}$ Godwin Chinyere Chinyere, ${ }^{4}$ Glory \\ Otuchristian and ${ }^{4}$ Nweke Chukwuemeka Nworie. \\ ${ }^{I}$ Department of Biochemistry, Michael Okpara University of Agriculture Umudike, Abia State, Nigeria. \\ ${ }^{2}$ Department of Animal and Environmental Biology, Abia State University, Uturu-Nigeria \\ ${ }^{3}$ Department of Biochemistry, Abia State University, Uturu-Nigeria \\ ${ }^{4}$ Department of Science Laboratory Technology, Akanu Ibiam Federal Polytechnic Unwana, Afikpo, Ebonyi
} State, Nigeria.

\begin{abstract}
The effect of aqueous and methanolic extracts of Vitex doniana leaves in serum lipid profile and liver enzymes in normal and alloxan-induced diabetic rats were investigated using standard analytical protocols. A total of 35 albino rats divided into seven groups of five rats each comprising one normal untreated group as animal control, one diabetic untreated group as diabetic control, one normal treated with $750 \mathrm{mg} / \mathrm{kg}$ body weight as reference group, three diabetic groups treated with 250,500 and $750 \mathrm{mg} / \mathrm{kg}$ body weight respectively and one diabetic group treated with $5 \mathrm{mg} / \mathrm{kg}$ Glibenclamide as standard. The result of acute toxicity test obtained indicated lethal dose $\left(L D_{50}\right)$ of greater than $5000 \mathrm{mg} / \mathrm{kg}$ extract. The results showed that induction of diabetes caused significant $(P<0.05)$ elevation in the serum level of total cholesterol, triacylglycerides and low density lipoproteins, alkaline phosphatase, aspartate aminotransferase, and alanine aminotransferase and significant $(P<0.05)$ reduction in serum high density lipoproteins. The results indicated dose dependent significant $(P<0.05)$ reductions in the elevated total cholesterol, triacylglycerides and low density lipoproteins, alkaline phosphatase, aspartate aminotransferase, and alanine aminotransferase and significant $(P<0.05)$ increase in high density lipoprotein in the reference and diabetic groups when compared to normal and diabetic control groups respectively after oral administration of Vitex doniana leaf extracts. It could therefore be concluded that Vitex doniana leaf extract is safe, medicinal and have anti-lipidemia properties and hepatoprotective effects.
\end{abstract}

Key words: Vitex doniana, Serum lipid profile, Liver marker enzymes, Diabetes, Lethal dose.

\section{Introduction}

Plants are known to be efficacious and most often could contain compounds that are potential drugs which would require further examinations. Interest in and the research for medicines from natural sources has served as catalyst for exploring techniques of obtaining the required plants and probing their activities (Edeoga et al., 2005). Various parts of the plants are used by traditional medicine practitioners in the management and treatment of several disorders which include cancer, rheumatism, hypertension and inflammatory diseases among others (Atawodi, 2005). Leaf extracts or infusion of Vitex doniana plant has been claimed by many traditional medicine practitioners to be effective in the treatment and management of many ailments, such as diabetes mellitus, ulcer, and gastrointestinal tract infections among others (Bethesda, 2009; Beentje, 1994).

Vitex doniana, a member of Verbenaceae family is a medium-sized deciduous tree with a heavy rounded crown and a clear bole up to $5 \mathrm{~m}$. It is widely distributed in the Eastern and Western parts of Nigeria. The plant commonly called Black plum (English), Dinya (Hausa), Oriri (Yoruba), and Ucha koro (Igbo), is a deciduous ever green tree, usually 4-8 metres high occasionally up to 15 metres with a dense rounded crown. Its bark is light grey with numerous vertical fissures. Branches are not hairy and leaves are long stalked with 5-7 leaflets (NNMDA, 2008). The bases of old trees have oblong scales. Leaves are opposite, glabrous, $14-34 \mathrm{~cm}$ long, usually with 5 leaflets on stalks $6-14 \mathrm{~cm}$ long. Leaflets distinctly stalked, ovate, obovate-elliptic or oblong. Flowers on petals are white except on largest lobe, which is purple, in dense opposite and auxiliary cymes. Flowers are small, blue or violet, $3-12 \mathrm{~cm}$ in diameter, only a few being open at a time (Beentje, 1994; Keay and Onochie, 1964; Hutchinson and Dalziel, 1963).

Vitex doniana has numerous applications in traditional medicine. Leaf sap is used as an eye drop to treat conjunctivitis and other eye complaints. A leaf decoction is applied externally as a galacatagogue and against headache, stiffness, measles, rash, fever, chickenpox and hemiplegia, and to treat respiratory diseases. Leaf extract is used for treatment and management of diabetes mellitus. Powdered bark added to water is taken to treat colic, and a bark extract is used to treat stomach complaints and kidney troubles (Bethesda, 2009). Other 
medical applications include treatment against mental illness, rheumatism, as anthelmintic and tranquilizer, gastrointestinal disturbance, urinary ailments etc (Beentje, 1994). Also Kilani (2006) have assessed the stem bark of V. doniana for antibacterial activity and establish its efficacy in the management of dysentery and gastroenteritis infections. The root is used for treatment of gonorrhoea, and women drink a decoction of it for backaches (Beentje, 1994).

Phytochemical analysis of the various parts of the plant extract revealed the presence of saponin, tannins, phenols cardiac glycosides, flavonoids, sterols and triterpenes as well as high concentration of sodium, Patassium Calcium, iron, phosphorus and sulphur (Abdulrahman, 1992). The therapeutic applications of this plant's parts in ethno-medicine for the treatment and management of numerous diseases calls for a high thorough put investigations of the safety and wholesomeness. Therefore, this research is aimed at evaluating the effects of aqueous and methanolic extract of Vitex doniana leaf on the serum lipid profile and liver enzyme levels in normal and alloxan induced diabetic albno rats.

\section{Collection and Identification of Plant Materials}

\section{Materials and Methods}

Leaves of Vitex doniana were collected from a nearby farm- land in Unwana, Afikpo North, Ebonyi State and authenticated by the Akanu Ibiam Federal Polytechnic Unwana curator, Dr. M.C. Okafor (Taxonomists) of the Department of Science Laboratory Technology.

\section{Preparation of the Extract}

The leaves were air dried and grinded to powder using electric blender. Exactly $2.0 \mathrm{~kg}$ of the powder sample were soaked in 2.01 of methanol for 48 hours at room temperature. Removal of the solvent from the extract under reduced pressure yielded $200 \mathrm{~g}(10 \%)$ of a dark green residue. This residue was put in hexane to remove its hydro-insoluble component. Following filteration through Whatman No.42 filter paper, the filterate was again dissolved in ethyl acetate. The final residue obtained (neither soluble in hexane nor ethyl acetate) constitute the methanolic residue extract of $\mathrm{V}$. doninana. The purpose of this extraction procedure was to obtain a hydro-soluble organic extract which was closer to aqueous extract normally used traditionally. This extract was solubilized in distilled water prior to administering to the experimental animals.

\section{Experimental Animals}

Male albino wister rats of same age group and body weight between 150-200g were selected for all the experiments. The rats were obtained from the animal facility units of university of Nigeria, Nsukka. They were kept and maintained under standard laboratory conditions of temperature, humidity in a wooden cage, 12-hour day, 12-hour night cycle and allowed access to rat feed (Grower Pellet of Royal feeds, Enugu) and clean water ad libitum.

\section{Acute Oral Toxicity Studies $\left(\mathbf{L D}_{50}\right)$}

The acute oral toxicity study was conducted using the limit doses test of up and down procedure according to organization for economic and cultural development (OECD) test guidelines 425, (2001) and Dixon, (1991). Five groups of rats (one rat in each group) were used for this experiment. They were housed individually after random selection and were allowed to acclimatize to the laboratory conditions for five days. A limit dose of $5,000 \mathrm{mg} / \mathrm{kg}$ body weight of the extract was used. Animals were dosed one at a time and observed at least during the first 24 hours and then for another 24 hours (observation time 48 hours) and thereafter for a total of 14days. At the expiration of initial 48 hours, four additional animals were subsequently dosed and observed as previously described. Animals were observed for signs of acute toxicity morbidity and mortality. The behavioural changes and other changes observed in the experimental rats were recorded according to OECD, (2001) 425 guidelines.

\section{Induction of Diabetes in Experimental Rats}

The rats were acclimatized for seven days and diabetes were induced by intraperitoneal administration of aqueous alloxan monohydrate $(80 \mathrm{mg} / \mathrm{kg}$ ) to a group of overnight fasted rats but were not deprived of water. After three days, the blood glucose level of the animals was checked using a glucometer (a one touch test strip) to ascertain a diabetic state. Depending upon their blood glucose levels, the rats were divided into seven groups with five rats each. Rats were kept for 15 days before the beginning of the experiment to stabilize the diabetic conditions and to allow complications to appear.

\section{Test for Diabetic Activity}

In the experiment, a total of 35 rats ( 25 diabetic surviving rats, 10 normal rats) were divided into seven groups as shown on table 1 


\section{Preparation of Blood Serum and Assays}

The rats were sacrificed by decapitation after mild chloroform anaesthesia, 24 hours after the last treatment. The blood samples obtained were collected using sterilized syringe and needle into test tubes and centrifuged at $3000 \mathrm{rpm}$ for 5 minutes, the sera collected were used for biochemical analysis.

\section{Biochemical Lipid Profile and Liver Enzymes Assay}

Total serum cholesterol was determined according to the method of Richmond (1973). The quantitative method of Bucalo and David (1973) was used to determine the triacylglycerol concentrations of the experimental animals. Low Density Lipoproteins (LDL)-cholesterol estimation was done according to the method of Assmann et al. (1984) while High Density Lipoproteins (HDL)-cholesterol estimation was done using the method of Lopes-Virella et al. (1997). Randox Diagnostic Kit (Randox Laboratories Ltd, UK) was used for all the experiments in lipid profile analysis.

Serum Alanine Aminotransferase (ALT), Aspartate Aminotransferase (AST), and Serum Alkaline Phosphatase (ALP) were estimated colorimetrically using Randox Diagnostic Kit (Randox Laboratories Ltd, UK) based on the methods of Reitman and Frankel (1957), and King and Kind (1954) respectively.

\section{Statistical Analysis}

All data obtained were expressed as mean \pm S.E.M (standard error of mean). Statistical significance of the results between groups was determined using one way analysis of variance (ANOVA) followed by Duncan's Post Hoc test to check differences between the individual groups and differences in means were considered to be significant at $\mathrm{P}<0.05$. All statistical analysis were carried out using the instat statistic package (instat software, Ver 16.0, Sandiago USA).

\section{Acute Oral Toxicity Studies}

\section{Results}

Response and effect on the body weight of rats treated for 14 days with $5000 \mathrm{mg} / \mathrm{kg}$ leaf extract of V. doniana is shown on table 2 . The results showed that all rats treated with the $5000 \mathrm{mg} / \mathrm{kg}$ limit dose of the leaf extract were hypo-reactive to external stimuli such as touch in the first 30minutes to 1 hour post administration and subsequently became active and exhibited normal behaviour throughout the 14days observation period. The limit test does of $5000 \mathrm{mg} / \mathrm{kg}$ did not cause any mortality or any major acute toxicity. However, the high does induced progressive and sustained weight loss in all the five treated rats (table 2). The $\mathrm{LD}_{50}$ of the leaf extracts using the OECD (2001) guidelines is therefore greater than $5000 \mathrm{mg} / \mathrm{kg}$ because there was no death at all during or after the administration.

\section{Result of Biochemical Profile Study}

The results of the effect of leaf extract of Vitex doniana on the lipid profile are presented in Table 3. The results showed that induction of diabetes mellitus significantly $(\mathrm{P}<0.05)$ elevated the level of serum total cholesterol, triacylglycerol and Low Density Lipoproteins (LDL) cholesterol but significantly $(\mathrm{P}<0.05)$ lowered the serum level of High Density Lipoprotein (HDL) cholersterol in the rats. The results (Table 3) also showed that oral administration of leaf extracts of Vitex doniana significantly $(\mathrm{P}<0.05)$ lowered the serum levels of total cholesterol, triacylglyerides and LDL-cholesterol but significantly $(\mathrm{P}<0.05)$ elevated the serum level of HDLcholesterol in the normal and diabetic treated rats in a dose-dependent manner.

The effect of the leaf extract of Vitex doniana on the liver marker enzymes, aspartate aminotransferase (AST), alanine aminotransferase (ALT) and alkaline phosphatase (ALP) of the normal and diabetic treated rats are presented in Table 4. The results showed that induction of diabetes mellitus caused significant $(\mathrm{P}<0.05)$ elevations in serum liver marker enzymes evaluated. The results (Table 4) also showed that oral administration of the leaf extracts of Vitex doniana significantly $(\mathrm{P}<0.05)$ lowered the serum levels of the studied liver marker enzymes in the normal and diabetic treated rats in a dose-dependent manner.

\section{Acute Toxicity Studies}

\section{Discussion}

The results of acute toxicity study indicated that the $\mathrm{LD}_{50}$ of the leaf extract of $\mathrm{V}$. doniana is greater than $5000 \mathrm{mg} / \mathrm{kg}$ body weight. The limit test dose is primarily used in situations where the experimenter has information indicating that the test material is likely to be non-toxic or of low toxicity (OECD, 2001). Thus, the non-lethal effects produced with the high dose of this extract are an indication that the leaf extracts of V. doniana is relatively safe on acute oral exposure. It can therefore be concluded that V. doniana leaf extracts is non-toxic which is in agreement with Bruce (1987) and American society for testing and materials (1987), that any chemical substance with $\mathrm{LD}_{50}$ estimate greater than $3000-5000 \mathrm{mg} / \mathrm{kg}$ (oral route) could be considered of low toxicity and safe. OECD, 2001 also recommended the use of limit test dose with $\mathrm{LD}_{50}$ greater than 
$5000 \mathrm{mg} / \mathrm{kg}$ (oral route) as having low acute oral toxicity. This therefore implies that the leaf extract of V. doniana is relatively safe.

\section{Biochemical Profile Study}

Diabetes mellitus affects drastically serum lipid profiles leading to complications with severe consequences (Lacerf and Lorgeril, 2011; Murray et al., 2000; Zilva et al., 1991). High levels of total cholesterol and more importantly LDL-Cholesterol in blood are major cardiovascular risk factors (Okili, 2010). Insulin deficiency causes an increase in free fatty acid mobilization from adipose tissues which results in increased production of cholesterol rich LDL particle and dyslipidaemia (Murray et al., 2000; Zilva et al., 1991). The results showed that Vitex doniana extracts significantly brought down the elevated cholesterol, triacylglyerides and LDL-cholesterol levels after 5 days of treatment and also increased the HDL level in the normal and diabetic treated rats (Table 3). In recent times, there has been a decline in the prevalence of artherosclerosis and artherosclerosis related deaths possibly due to effective management of the risk factors that predispose to this disorder. Lowering of serum lipid concentrations, particularly LDL is therefore considered as one of the strategies that can delay the on-set of chronic disorders associated with hyperlipidemia in humans (Ghasi et al, 2000; Massing et al, 2001; Marylatha et al., 1998). Herbal extracts are often used in folk medicine to improve the lipid profile in humans (Chattopadhyay and Bandyopdhyay, 2005). In this study, the effects of leaf extract of Vitex doniana on the lipid profile of normal and diabetic rats have revealed that this plant could improve the lipid profile, particularly total cholesterol and LDLcholesterol.. This was deduced from the fact that the serum concentrations of these fractions in the treated animals were significantly $(\mathrm{P}<0.05)$ ) lower, in diabetic rats compared to the normal and control animals. On the other hand, HDL-cholesterol concentration was significantly $(\mathrm{P}<0.05)$ elevated (Table 3). Dietschy et al. (1993) reported that plasma clearance of LDL particles is mediated primarily by LDL receptors, a large complement of which is expressed by the liver and that LDL become atherogenic when they are modified by oxidation reaction (Steinberg, 1997). Biochemically, the Vitex doniana leaf extract might be inducing rapid catabolism of low-density lipoprotein cholesterol through hepatic receptors for final elimination in the form of bile acids as has been suggested by numerous researchers (Chattopadhyay and Bandyopdhyay, 2005).

The significant $(\mathrm{P}<0.05)$ elevation of liver biomaker enzymes such as ALP (alkaline phosphatase ) AST (aspartate aminotransferase), and ALT (alanine aminotransferase) in the diabetic rats (Table 4) indicated hepatic damage (Rathod et al., 2009). The liver enzymes found within organs and tissues are released into the bloodstream following cellular necrosis and cell membrane permeability and are used as diagnostic measure of liver damage (Sanjiv, 2002). Damage to structural integrity of tissues is always reflected by an increase in some of these enzymes in the serum, probably through leakage from the altered cell membrane structure (Gaze, 2007). Therefore, the corresponding increase in serum ALP activity following induction of diabetes confirms damage to the plasma membrane, leading to compromise of its integrity (Yakubu et al., 2003). Loss of ALP activity from the tissue may hinder adequate transportation of required ions or molecules across the cell membrane (Akanji et al., 1993). It may also affect other metabolic processes such as the synthesis of nuclear proteins, nucleic acids, phospholipids, and cleavage of phosphate esters that require the enzyme (Ramalingam and Vimaladevi, 2002). The aminotransferases (ALT and AST) considered in this study are useful "marker" enzymes of liver cytolysis (Yakubu et al., 2005; Shahjahan et al., 2004). The enzymes occupy a central position in the metabolism of amino acids as they help to retain amino groups (or to form a new one) during the degradation of amino acids. Increase in serum AST and ALT activity following induction of diabetes (Table 4) confirms damage to the liver cells, leading to compromise of its integrity (Ubani et al., 2011; Lange et al., 1982). The ability of the leaf extract to lower the activities of these studied serum marker enzymes in diabetic rats in a dose-dependent manner may be attributed to its bioactive contents such as flavonoids, saponin, tannins, phenols cardiac glycosides (Abdulrahman, 1992). Thus, Vitex doniana leaf extract can be said to have hepatoprotective properties.

\section{Conclusion}

The results of the study have shown that induction of diabetes mellitus causes hyperlipidaemia and demage to liver cells. Oral administration of Vitex doniana leaf extract to the normal and diabetic rats has shown that the plant extract has lowering effects on the total cholesterol, triacylglycerides and LDL-cholesterol and raising effects on HDL-cholesterol. This showed that the plant leaf extracts exhibit hypolipidaemia effects. The ability of the extract to lower the raised liver biomarker enzymes showed that it is hepato-protective. Further research is necessary to not only isolate these bioactive compounds in the plants' leaf but also elucidate the various mechanism of action for enhanced utilization of this plant part in phyto-medicine. 


\section{References}

[1]. Abdulrahman,F.I. (1992). Studies in natural Products Chemistry: The Moraceae in African traditional medicine and management of psychiatry in Borno state. M.S.c. Thesis, University of maidugiri, Maidugeri, Borno State., Nigeria.

[2]. Akanji MA, Olagoke OA, Oloyede OB: Effect of chronic consumption of metabisulphite on the integrity of rat cellular system. Toxicology 1993;81:173-179.

[3]. American Society for testing and Materials. (1987). Standard test method for estimating Acute Oral Toxicity of Rats. American Society for Testing and Materials E. 116387, Philadelphia, U.S.A. Pp 84.

[4]. Assmann, G. Jabs, H.U. Nolte, W. and Schriewer, H. (1984). LDL-cholesterol determination in

[5]. blood serum following precipitation of LDL with polyvinyl sulfate. Clinica. Chimica. Acta. 140:77-83

[6]. Atawodi, S.E. (2005). Comparative in vitro trypanocidal activities of petroleum ether, chloroform, methanol, and aqueous extracts of $\quad$ some Nigerian Savannah plants, African Journal of Biotechnology. 4(2): 177-182

[7]. Beentje, H. J. (1994). Kenya trees, shrubs and lianas. National Museums of Kenya.5:7-11

[8]. Bethesda, M. D. (2009). Stem cell Markers in Stem cell Information. J. Dent. Res. 65 (2):125-127.

[9]. Bruce, R.D (1987). A Confirmatory Study of up-and-down Method of Acute Oral Toxicity Testing. Undamental Applied Toxicology. 8: 97-100.

[10]. Bucalo, G. and David, H. (1973). Quantitative determination of serum triacylglycerols by use

[11]. of enzymes. Clini. Chem. 19:476-482.

[12]. Chattopadhyay, R.R and M. Bandyopadhyay (2005). Effect of Azadirachta indica leaf extract on serum lipid profile changes in normal and streptozotocin induced diabetic rats. African J. Biomed. Res., 8:101-104.

[13]. Dietschy, J.M., Turley, S.D., and Spady, D.K. (1993) Role of liver in the maintenance cholesterol and low density lipoprotein homeostasis in different animal species, including humans. J. Lipid Res., 34:1637-1659.

[14]. Dixon, W.J. (1991) Staircase Bioassay. The up-and-down method. Neuro Sci. Biobehar, Rev. 15: 47-50.

[15]. Edegoa, H.O., Okwu, D. E. and Mbaebie, B.O. (2005). Photochemical Constituents of some Nigeria Medicinal Plants. Afri. J. Biotechnol. 4:685-688.

[16]. Gaze, D.C. (2007). The role of existing and novel cadiac biomarkers for cardio-protection. Curr.opin. Invest. Drugs 8 (9) :711,7

[17]. Ghasi, S.; Nwobodo, E and Ofili, J.O. (2002). Hypocholesterolemic effects of crude extract of leaf of Moringa oleifera Lam in high-fat diet fed Wistar rats. J.Ethnopharm. 69:21-25

[18]. Hutchinson, J. and Dalziel, J.M. (1963).Flora of west tropical African Crown Agents, London. Pp 57-66.

[19]. Keay, R.W.J. and Onochie, C.F.A. (1964). Nigeria Tress. Department of Forest Research, Ibaden, Nigeria. Pp 567-571..

[20]. Kilan. A.M. (2006). Antibacterial assessment of whole stem bark of Vitex doniana against some eterobactericease. Fa. J., Biotechnol. 5:958.

[21]. Kind, P.R. and King, E.J. (1954). Estimation of plasma phosphatase by determination of hydrolysed phenol with aminoantipyrine. Journal Clin Pathol. 7(4):322-326.

[22]. Lange, P/H., Millan, J.L., Stigbrand, T., Vessella, R.L., Ruoslahti, E. phophatase as a tumor marker for seminoma: Cancer Res. 42 (8): 3244-7

[23]. Latha RM, Geentha T, Varalakshmi P: Effect of Vernonia cinerea Less. flower extract in adjuvant-induced arthritis. Gen Pharmacol 1998;31:601-606.

[24]. Lecerf. J.M, and Lorgeril, M. (2011). Dietary Cholesterol: From Physiology to cardiorascular risk. B. Jnutr. 106 (1): 6-14.

[25]. Lopes-Virella, M.F., Stone, P., Ellis, S. and Cohwel, J.A. (1997). Quantitative determination of HDL-Cholesterol in serum or plasma by phosphotunstate method. Clin Chem 23: 882- 886.

[26]. Massing, M.W., Sueta. C.A., Chowdhury, M; Biggs, D.P.; Simpson, R.J. R.J. Jr (2001). Lipid

[27]. management among coronary artery disease patients in diabetes mellitus or advanced age

[28]. Am. J. Cardiol, 87:646-664

[29]. Murray, R.K., Granner, D.K., Mayes, P.A. and Rodwell, V.W. (2000). Harper's Biochemistry (20th ed). McGraw-Hill, New York. Pp. 594-602.

[30]. NNMDA (2008). Medicinal plants of Nigeria, South-East Zone Vol.1. Nigeria Natural Medicine Development Agency, Federal Ministry of Science and Technology, Nigeria. Lisida Consulting, Lagos. Pp 8-159.

[31]. OECD (2001). Organisation for Economic and Cultural Development: Guidelines for Testing Chemicals, Acute Oral Toxicit up and down Procedure. 425 1-26.

[32]. Okoli, C.O., Ibiam, A.F., Ezike, A.C., Akah, P.A and Okoye, Z.C. (2010). Evluation of anti-diabetic potentials of phyllanthus nitri in alloxan diabetic rats. African Journal of Biotechnology. 9:245259.

[33]. Ramalingam V, Vimaladevi V: Effect of mercuric chloride on membrane-bound enzymes in rat testis. Asian J Androl 2002;4:309311.

[34]. Rathod, N.R., reghureer, I., Chotine, H.R and Chanda, R. (2009). Free radical scavenging activity of calotropis gigamtea on streptozotocin induced diabetic rats. Indian Journal of Pharmaceutical Science. 71:615-621.

[35]. Reitman, S. and Frankel, S. (1957) A colorimetric method for the determination of serum glutamate - oxaloacetic acid and glutamate - pyruvic acid transaminases. Amer J. Clin Path. 28:56-63.

[36]. Richmond, N. (1973). Determination of cholesterol in serum. Clini. Chem.19:1350-1356.

[37]. Sanjiv, C. (2002). The liver book: A comprehensive guide to diagnosis, treatment and recovery. Atria Jimcafe Company.

[38]. Shahjahan, M., Sabitha, K.E., Mallika, J. and Shyamala-Devi, C.S. (2004). Effect of Solanum trilobatum against carbon tetrachloride induced hepatic damage in albino rats. Indian J Med Res 120:194-198.

[39]. Steinberg, D. (1997). Low density lipoprotein oxidation and its pathological significance. J. Biol. Chem., 272:20963 - 20966.

[40]. Ubani, C.S., Joshua, P.E. and Anieke, U.C. (2011). Effects of aqueous extract of Hibiscus sabdariffa L. calyces on liver marker enzymes of phenobarbitone-induced adult wistar albino rats. J. Chem. Pharm. Res., 3(4): 528-537

[41]. Yakubu, M.T., Bilbis, L.S., Lawal, M. and Akanji, M.A. (2003). Effect of repeated administration of sildenafil citrate on selected enzyme activities of liver and kidney of male albino rats. Nig J Pure Appl Sci 18:1395-1400.

[42]. Yakubu, M.T., Bilbis, L.S., Lawal, M. and Akanji, M.A. (2005). Responses of male rat liver and heart amino transferases to chronic administration of yohimbine. Centrepoint (Sci Ed) 2:124-131.

[43]. Zilva, J.F., Panmall, P.R. and Mayne, P.D. (1991). Clinical Chemistry in Diagnosis and Treatment (5th ed). England Clays Ltd., London. Pp. 210-212. 
Table 1: Different group of rats treated with different dose of the extract.

\begin{tabular}{|c|c|}
\hline Groups & Treatments \\
\hline Group 1 & Normal untreated rats (animal control) \\
\hline Group 2 & $\begin{array}{l}\text { Normal rats given only the extract }(750 \mathrm{mg} / \mathrm{kg} \text { body weighty) in aqueous solution } \\
\text { daily by oral administration for } 5 \text { consecutive days. }\end{array}$ \\
\hline Group 3 & Diabetic untreated rats (diabetic control) \\
\hline Group 4 & $\begin{array}{l}\text { Diabetic rats given extract }(250 \mathrm{mg} / \mathrm{kg} \text { body weight) in aqueous solution daily by } \\
\text { oral administration for } 5 \text { consecutive days. }\end{array}$ \\
\hline Group 5 & $\begin{array}{l}\text { Diabetic rats given extract }(500 \mathrm{mg} / \mathrm{kg} \text { body weight) in aqueous solution daily by } \\
\text { oral administration for } 5 \text { consecutive days. }\end{array}$ \\
\hline Group 6 & $\begin{array}{l}\text { Diabetic rats given extract }(750 \mathrm{mg} / \mathrm{kg} \text { body weight) in aqueous solution by daily } \\
\text { oral administration for } 5 \text { consecutive days }\end{array}$ \\
\hline Group 7 & $\begin{array}{l}\text { Diabetic rats given Daonil ( } 5 \mathrm{mg} / \mathrm{kg} \text { body weight) in aqueous solution by daily oral } \\
\text { administration for } 5 \text { consecutive days }\end{array}$ \\
\hline
\end{tabular}

Table 2: Response and effect on the body weight of rats treated for 14 days with $5000 \mathrm{mg} / \mathrm{kg}$ leaf extract of Vitex doniana

\begin{tabular}{|c|c|c|c|c|c|c|}
\hline \multirow[t]{2}{*}{$\begin{array}{l}\text { Test } \\
\text { sequence }\end{array}$} & \multirow[t]{2}{*}{$\begin{array}{l}\text { Animal } \\
\text { identity }\end{array}$} & \multirow[t]{2}{*}{$\begin{array}{l}\text { Doses } \\
\text { (mg/kg) }\end{array}$} & $\begin{array}{l}\text { Body } \\
\text { Day }\end{array}$ & $\begin{array}{l}\text { sht } \\
\text { Day } \\
\text { Day }\end{array}$ & & \multirow[t]{2}{*}{$\begin{array}{l}\text { Short } \\
\text { term } \\
\text { outcome }\end{array}$} \\
\hline & & & 0 & 7 & 14 & \\
\hline 1 & 01 & 5000 & 197 & $\begin{array}{l}184 \\
161\end{array}$ & & 0 \\
\hline 2 & 02 & 5000 & 168 & $\begin{array}{c}153 \\
141\end{array}$ & & 0 \\
\hline 3 & 03 & 5000 & 165 & $\begin{array}{l}148 \\
137\end{array}$ & & 0 \\
\hline 4 & 04 & 5000 & $\begin{array}{l}154 \\
133\end{array}$ & 146 & & 0 \\
\hline 5 & 05 & 5000 & 187 & $\begin{array}{c}176 \\
158\end{array}$ & & 0 \\
\hline
\end{tabular}

NB: $0=$ mean death.

Table 3: Effect of Leaf Extract of Vitex Doniana on Lipid Profile of Control and Diabetic Rats.

\begin{tabular}{|c|c|c|c|c|}
\hline $\begin{array}{l}\text { Treatment } \\
\text { Group }\end{array}$ & $\begin{array}{l}\text { Cholesterol } \\
(\mathbf{m g} / \mathbf{d l})\end{array}$ & $\begin{array}{l}\text { Triacylgylerides } \\
\text { (mg/dl) }\end{array}$ & $\begin{array}{l}\text { HDL } \\
\text { Cholesterol } \\
\text { (mg/dl) }\end{array}$ & $\begin{array}{l}\text { LDL } \\
\text { Cholesterol } \\
\text { (mg/dl) }\end{array}$ \\
\hline Normal control & $\begin{array}{ll}64.30^{\mathrm{b}} & \pm \\
0.12 & \end{array}$ & $59.70^{b} \pm 0.14$ & $96.80^{b} \pm 0.24$ & $63.74^{b} \pm 0.28$ \\
\hline $\begin{array}{l}\text { Control } \\
750 \mathrm{mg} / \mathrm{kg} \text { extract }\end{array}$ & $56.50^{\mathrm{a}} \pm 0.20$ & $43.28^{a} \pm 0.10$ & $101.84^{\mathrm{f}} \pm 0.17$ & $59.50^{\mathrm{a}} \pm 0.21$ \\
\hline Diabetic control & $\begin{array}{l}293.90^{\mathrm{f}} \\
1.26\end{array}$ & $187.00^{\mathrm{f}} \pm 0.26$ & $92.05^{\mathrm{a}} \pm 0.21$ & $204.80^{f} \pm 1.32$ \\
\hline $\begin{array}{l}\text { diabetic }+250 \\
\mathrm{mg} / \mathrm{kg} \text { extract }\end{array}$ & $\begin{array}{l}124.90^{\mathrm{b}} \quad \pm \\
1.10\end{array}$ & $94.14^{\mathrm{e}} \pm 0.23$ & $97.30^{\mathrm{bc}} \pm 0.16$ & $74.50^{\mathrm{b}} \pm 0.23$ \\
\hline $\begin{array}{l}\text { Diabetic }+ \\
500 \mathrm{mg} / \mathrm{kg} \text { extract }\end{array}$ & $\begin{array}{l}93.15^{\mathrm{de}} \\
\pm 1.25\end{array}$ & $65.30^{\mathrm{d}} \pm 0.19$ & $98.40^{\mathrm{d}} \pm 0.25$ & $68.10^{\mathrm{e}} \pm 0.30$ \\
\hline $\begin{array}{l}\text { Diabetic } \\
750 \mathrm{mg} / \mathrm{kg} \text { extract }\end{array}$ & $76.70^{c} \pm 1.36$ & $61.05^{\mathrm{c}} \pm 0.21$ & $99.85^{\mathrm{e}} \pm 0.12$ & $66.80^{c} \pm 0.25$ \\
\hline $\begin{array}{l}\text { Diabetic + } \\
5 \mathrm{mg} / \mathrm{kg} \\
\text { Glibenclamide } \\
\text { (reference drug) }\end{array}$ & $\begin{array}{l}91.50^{\mathrm{d}} \\
0.25\end{array}$ & $61.75^{c} \pm 0.15$ & $96.90^{\mathrm{b}} \pm 0.32$ & $67.80^{\mathrm{d}} \pm 0.18$ \\
\hline
\end{tabular}

Means in a column with the sample superscripts are not significantly different $(\mathrm{P}<0.05)$ 
Table 4: Effect of extract of Vitex doniana on liver marker enzymes of control and diabetic rats.

\begin{tabular}{llll}
\hline Treatment Group & ALP $(\mu / \mathrm{l})$ & AST $(\mu / \mathrm{l})$ & ALT $(\mu / \mathrm{l})$ \\
\hline Normal control & $119.70^{\mathrm{c}} \pm 0.06$ & $69.30^{\mathrm{c}} \pm 0.16$ & $34.18^{\mathrm{d}} \pm 0.11$ \\
$\begin{array}{l}\text { Control }+750 \mathrm{mg} / \mathrm{kg} \\
\text { extract }\end{array}$ & $102.30^{\mathrm{a}} \pm 1.12$ & $58.80^{\mathrm{a}} \pm 0.32$ & $23.50^{\mathrm{a}} \pm 0.26$ \\
$\begin{array}{l}\text { Diabetic control } \\
\text { diabetic }+250 \mathrm{mg} / \mathrm{kg}\end{array}$ & $148.32^{\mathrm{b}} \pm 0.84$ & $74.08^{\mathrm{b}} \pm 0.28$ & $48.70^{\mathrm{f}} \pm 0.32$ \\
$\begin{array}{l}\text { extract } \\
\begin{array}{l}\text { Diabetic }+500 \mathrm{mg} / \mathrm{kg} \\
\text { extract }\end{array}\end{array}$ & $125.90^{\mathrm{d}} \pm 0.36$ & $71.90^{\mathrm{d}} \pm 0.12$ & $39.60^{\mathrm{b}} \pm 0.22$ \\
$\begin{array}{l}\text { Diabetic }+750 \mathrm{mg} / \mathrm{kg} \\
\text { extract }\end{array}$ & $110.80^{\mathrm{b}} \pm 1.17$ & $68.12^{\mathrm{b}} \pm 0.93$ & $35.15^{\mathrm{e}} \pm 0.17$ \\
$\begin{array}{l}\text { Diabetic }+5 \mathrm{mg} / \mathrm{kg} \\
\begin{array}{l}\text { Glibenclamide } \\
\text { (reference drug) }\end{array}\end{array}$ & $120.10^{\mathrm{c}} \pm 1.24$ & $72.30^{\mathrm{d}} \pm 0.13$ & $28.15^{\mathrm{b}} \pm 0.17$ \\
\hline
\end{tabular}

Values are means \pm standard error of five replications.

Mean in a column with the same superscripts are not significantly different $(\mathrm{P}<0.05)$. 